\title{
МАТЕМАТИЧНЕ МОДЕЛЮВАННЯ ВПЛИВУ КОМПЛЕКСУ ПРОЦЕДУР МАСАЖУ НА ПАЦІЄНТА ТА МАСАЖИСТА
}

Д. В. Вакуленко

\section{ДВНЗ «Тернопільський державний медичний університет імені І. Я. Горбачевського МОЗ України» \\ MATHEMATICAL MODELING OF INFLUENCE COMPLEX PROCEDURES OF MASSAGE ON PATIENTS AND MASSEURS}

\section{V. Vakulenko}

\author{
SHEI «Ternopil State Medical University by I. Ya. Horbachevsky of MPH of Ukraine»
}

Вступ. Ефективність масажу значною мірою залежить від правильного призначення масажу лікарем. Мова йде про вибір ділянки та методу (дозування) масажу. У вітчизняних і зарубіжних літературних джерелах систематизованого підходу до зазначеної проблеми нами не знайдено.

Мета роботи: представлення спрощеної математичної моделі взаємодії комплексу процедур масажу для кількісної оцінки впливу на його учасників - пацієнта та масажиста.

Результати та їх обговорення. Засобом взаємодії між масажистом та пацієнтом є процедура масажу, а для кількісної оцінки впливу на учасників процедури (пацієнта та масажиста) використовується система звичайних диференційних рівнянь.

Стан кожного учасника (масажиста та пацієнта) відображають показники, що є індикаторами основних регуляторів організму: шкіра, нервова система, гуморальні механізми, лімфатична, серцево-судинна системи, м'язи, внутрішні органи, обмін речовин, газообмін, видільна функція, зв'язково-суглобовий апарат, ступінь гармонізації біоритмів різних органів. Обрані індикатори станів вищеперерахованих регуляторів гомеостазу організму формують матриці стану пацієнта та масажиста.

Матриця стану пацієнта $A=\left[x_{1}, x_{2}, x_{3}, \ldots x_{n}\right]$ В свою чергу $M=\left[m_{1}, m_{2}, m_{3}, \ldots m_{n}\right]$ відображає матрицю процедури масажу. Матриця $C=\left[c_{1}, c_{2}, c_{3}, \ldots c_{n}\right]$ відображає фізіологічні параметри масажиста. Коефіцієнт $\boldsymbol{k}$ визначає ступінь сприйняття процедури масажу пацієнтом, а коефіцієнт $\boldsymbol{d}$ відображає ступінь взаємодії масажиста 3 пацієнтом під час проведення процедури масажу. $\mathrm{k}, \boldsymbol{d}$ змінюються від 0 до 1.

$$
\begin{aligned}
& \frac{d P(t)}{d t}=k M * P(t) * C(t) \\
& \frac{d C(t)}{d t}=d M * P(t) * C(t)
\end{aligned}
$$

Для рівняння (1) задамо початкові умови:

$$
P(t)=A_{0}, \quad C(t)=C_{0}
$$

Рівняння (1) 3 початковими умовами (2) складає математичну модель процедури масажу.

Висновки. Автором узагальнено механізми впливу процедури масажу на різні системи, органи та тканини пацієнта та масажиста. Обрано репрезентативні показники досліджуваних складових та сформовано їх у матрицю-вектор стану пацієнта, масажиста та процедури масажу. Побудовану спрощену математичну модель процедури масажу перевірено в числовому експерименті. Порівняння розрахованих показників із отриманими в експерименті показало їх кореляцію між однойменними даними. 